norship of Dr John F. McCarthy, will hold its first meeting in 1987 , to be followed by meetings of a number of scientific working-groups to develop the specific programme shortly thereafter.

It is still too early to indicate the types of studies that will be undertaken but, to give an example, one of the proposals which appears likely to be chosen is that for a global-scale study of the ocean's euphotic zone. This was suggested by one of the above-mentioned four working-groups and has the long-term goal of predicting the potential impact of increasing tropospheric concentrations of radiatively active trace-gases on biogeochemical processes in the ocean that are influenced by, and feed back to, climate. It would include air-sea exchange processes, studies of estuarine and coastal zones, and also a wide range of transdisciplinary studies of marine ecosystems - including the problem of storage of fixed carbon in sea-water and sediments. The working group involved suggested that we need to improve our knowledge of the production and consumption of biogenic materials in the upper ocean, and how these will affect the global exchange of $\mathrm{CO}_{2}$ between the atmosphere and the oceans.

The suggestion for such a study of global change has generated great interest among scientists in many disciplines, who have come to realize more and more that the Geosphere and Biosphere are linked together by subtle, complex, and sometimes synergistic, processes - processes that need studying with a variety of techniques and methods, and that may need study over comparatively long periods of time before we shall be able to understand them fully. For example, we are now perceiving signals which indicate that Man is perturbing the natural environment. One of these is the atmospheric warming of about $0.5^{\circ} \mathrm{C}$ that has occurred, over the past 100 years, more steadily in the global record than in Northern Hemisphere land temperatures alone. We can exploit scientifically such perturbations to understand better than formerly, and to analyse, the sensitivities of the environment to natural and human influences.*

\section{Other ICSU Activities}

Toxic Waste Disposal:-The Berne General Assembly noted the conclusions of the report of the Special Committee on Toxic Waste Disposalt and the research needs outlined therein, and asked the ICSU Executive Board to consider the establishment of a working party, perhaps in conjunction with SCOPE, to look into practical ways in which ICSU bodies can contribute to the welfare of Mankind in respect of this most vitally important and pressing problem.**

Biotechnology:-The General Assembly created a Scientific Committee on Biotechnology, the first meeting of which is to be held in 1987 in Amsterdam, Netherlands. One of the studies which this Committee can be expected to undertake in close cooperation with other ICSU committees and with other international bodies, relates to the possible effects on the environment of the deliberate release of genetically altered organisms.

\section{F.W.G. BAKER, Executive Secretary International Council of Scientific Unions 51 Boulevard de Montmorency 75016 Paris, France.}

* Further information about the International Geosphere-Biosphere Programme may be obtained from Professor Thomas Rosswall, Executive Director of IGBP, Royal Swedish Academy of Sciences, Box 50005, S-10405 Stockholm, Sweden.-Ed.

$\dagger$ Available from the present Author.

** Including we would hope that of the concomitant disruption of Nature. - Ed.

\title{
Television Trust for the Environment
}

The first film to break the news of the famine in Ethiopia, establishment of an independent film-making unit in Brazil, major co-productions with the $\mathrm{BBC}$ on whaling and soil erosion, a European co-production on acid rain, publication of a critical film guide and of educational packs, and the first steps in the establishment of an information network for schools, are among the achievements outlined by the Television Trust for the Environment (TVE) in a report which has recently been published. The Report covers the progress of the editorially independent Trust in its first two years (April 1984-1986). In that period the UNEP- and Central TV-sponsored Trust mobilized close to $\$ 2$ millions for programmes and related projects on environment and development issues.

\section{Ethiopian Series}

TVE made its biggest impact with 'Seeds of Despair', the CENTRAL production which started the famine relief appeal three months before the $\mathrm{BBC} /$ Visnews news report made the big international breakthrough. It was broadcast in the United States by PBS as 'Cry Ethiopia Cry', later going on to win EMMY and Peabody Awards.

'Seeds of Despair' was the first instalment in a series on Ethiopia examining the underlying causes of famine in that unfortunate country. Filmed over two years under the direction of Charles Stewart, the follow-up programme 'Seeds of Hope', showed how exhaustion of the land pushed a village community into disaster. Viewers experienced for the first time what it is like to be on the receiving end of aid, as they saw a relief project disintegrate over a period of months.

A grant from the International Fund for Agricultural
Development (IFAD) then enabled the film crew to go back to Ethiopia to assess what effect the surge in international relief aid was having. The result was 'After the Harvest', a 30 minutes' documentary distributed by Worldwide TV News, which found that the aid was helping, but that the siutation was still critical. Charles Stewart is now back in Ethiopia, where he is following the fortunes of a family from the village who joined the Government's controversial resettlement programme.

The Ethiopian series exemplifies TVE's long-term approach to film-making, which aims to provide the viewer with an insight into how environmental problems develop-sometimes imperceptibly-over a period of years.

\section{Brazilian Series}

TVE's other main CENTRAL-sponsored project is 'Decade of Destruction', a co-production with Brazil's Federal University of Goiás, which is chronicling the fate of the Brazilian Amazon rain-forest. Recipient of the Geneva International Prize for the best film on a development issue, the first programmes in the series focused on the futility of the Amazon colonization schemes. The Brazilian versions have been shown on all of that country's major networks, where they have played an important role in alerting the public to the wastage of the forest's resources.

The next programme in the Amazonian series will be broadcast in 1987. In the process, CENTRAL and TVE are helping the Federal University of Goiás to establish a highly professional film-unit, capable of making its own films for Brazilian transmission when the current project comes to an end in 1990 . 


\section{Indian and Other Projects}

In Rajasthan, India, a similar project was started in 1984 which is following the peoples' struggle against the advancing desert. Two films made by an Indian crew based in New Delhi have been transmitted in India and distributed internationally by TVE and CENTRAL. TVE is now planning to develop a similar project in Zimbabwe.

Other projects involving North-South co-productions are planned. TVE is also giving small grants to help independent film producers to get films under way in China, Oman, and the Himalaya. Its most recent co-productions were with the $\mathrm{BBC}$ on whaling and soil erosion. A European co-production on acid rain involving CENTRAL, and TV stations in Austria, the Netherlands, and Sweden, was broadcast late in 1986.

Although TVE will continue to work in the background, helping to get new productions under way, it is giving priority to developing an international Clearinghouse sys- tem designed to promote the showing of more films on environmental issues. Its main aim will be to provide assistance to producers and broadcast outlets in 'developing' nations. TVE has already published a critical guide to some of the best films on environment and development. Nearly 1,000 films were viewed, out of which 100 were selected for the catalogue.

As part of the Clearinghouse project, TVE is also participating in a newly-launched scheme to provide students in developing countries with printed and audiovisual materials on environment and health. Support for this project has so far come from UNEP, WWF, UNICEF, and the New York Zoological Society.

Robert P. LAMB, Director

TVE Television Trust for the Environment 46 Charlotte Street

London WIP $1 L X$

England, UK.

\section{Environmental Successes Honoured by UNEP: The Global 500}

The United Nations Environment Programme has announced 90 awards in 43 countries for 'outstanding environmental achievements'-an initiative which has apparently been successful, attracting considerable media and political attention. Those honoured by UNEP ranged from an American actor. Robert Redford, to villagers in Africa, Asia, and Latin America. Redford received his UNEP award for supporting due protection of vulnerable areas by sound environmental management-an aim pursued by the Institute for Resource Management, which he founded.

UNEP Executive Director Dr Mostafa K. Tolba describes the awards, which recognize work in protecting and improving the environment, as 'tributes to success on the front lines of the global cause of the environment'. UNEP calls its awards list the 'Global 500', because it intends to select and recognize 500 such achievements over the five years to 1991. For this first batch of such awards, UNEP received more than 450 nominations of environmental activists, whether individuals or organizations, from 70 countries for the 1987 awards, and is already receiving nominations for 1988 .

The list of awards for 1987 was announced on the eve of World Environment Day, June 5, at UNEP's world headquarters in Nairobi, Kenya, and at national ceremonies elsewhere. (UNEP has published a 'Who's Who' booklet with brief descriptions of the work of the award winners, which is available on request from the undersigned.)

The first batch of 'Global 500' laureates include villagers protecting vulnerable farmlands and forests in remote areas of Africa, Asia, and Latin America, as well as prominent figures in science, diplomacy, politics, and the media, who are active in environmental causes.

Dr Tolba, the Egyptian microbiologist who has headed UNEP since 1976, presented the award certificates to a score of recipients who were able to be present in Nairobi. He told the large international audience at the ceremony: 'Their work for the environment deserves the thanks of the world. We hope their example will encourage others to preserve and enhance the environment which is the lifesupport system of our planet'.

The activities of the award-winners include forestry, marine research, wildlife protection, antipollution campaigns, energy-saving, urban renewal, soil and water conservation, film-making, legislation, and information.

There were 18 awards in Africa, 13 in Latin America, 17 in the Asia-Pacific Region, 3 in the Arab World, one in Israel, 13 in Western Europe, 6 in Eastern Europe, 3 in Canada, and 16 in the US.
Among the recipients of the UNEP awards on this occasion were:

- M. Bernard Ouedraogo, of Burkina Faso, Africa, leader of forest and water conservation projects in 700 villages in the Sahel.

- Miss Ulli Sigar, a popular Indonesian singer who uses music to take the message of environmental protection to villages in many parts of Java.

- Señor Carlos Pizani, field director of the Rapa Nui National Park on Easter Island in the Pacific Ocean.

- The National Geographic Society, USA, whose publications have, since 1890, reported in words and photographs on the world's natural heritage and cultures. At the awards ceremony in Nairobi, the Society presented a memorable audiovisual 'portrait of the beauty and diversity of the world.'

- Mrs Marion Stoddart, of Boston, USA, who successfully compaigned for cleansing of the polluted Nashua River in Massachusetts, USA.

- Mrs Lily Venizelos, of Greece, leader of campaigns to protect the Mediterranean breeding-grounds of marine turtles.

- Mr Sekkou Zouha, the leader of desert control projects in the Draa Valley, Morocco.

- Mr Ben Soans, whose village teams have planted millions of trees in southern India.

- Mrs Sophie Kiarie, of Kenya, who promotes village use of cookstoves designed to use less wood and thus save trees.

- Sir Edmund Hillary, the Himalayan climber who is now New Zealand Ambassador to Nepal, where he helped to found the national park near Mt Everest.

- Dr Grigory Galazii, a Soviet scientist who has long worked to prevent and reverse industrial pollution of Lake Baikal in Siberia.

- Mr Thomas Landgren, leader of a community group in Gallspang, Sweden, which is active in Nature conservation and control of waste disposal.

- The Green Great Wall Group, an organization of villagers planting millions of trees along the Great Wall of China, to conserve soil and moderate climate.

- The Arab Office of Youth and Environment, Cairo, the leading environmental action group in the Arabic-speaking world.

JoHN SHaw, Information Officer UNEP

P.O. Box 30552

Nairobi

Kenya. 